\title{
EVALUASI PEMBERIAN PROBIOTIK BACILLUS PADA MEDIA PEMELIHARAAN TERHADAP LAJU PERTUMBUHAN DAN PERUBAHAN HISTOPATOLOGI IKAN LELE DUMBO (Clarias gariepinus) YANG DIINFEKSI Aeromonas hydrophila
}

\author{
Angela Mariana Lusiastuti*\#, Mohammad Faizal Ulkhaq*), Widanarni, dan Tri Heru Prihadi* \\ *) Balai Penelitian dan Pengembangan Budidaya Air Tawar \\ *) Program Studi Budidaya Perairan, Universitas Airlangga, PDD Banyuwangi \\ (**) Depatemen Budidaya Perairan, Fakultas Perikanan dan IImu Kelautan, Institut Pertanian Bogor
}

\begin{abstract}
ABSTRAK
Penelitian ini bertujuan untuk mengevaluasi pemberian probiotik Bacillus melalui media pemeliharaan terhadap laju pertumbuhan dan perubahan histopatologi ikan lele dumbo yang diinfeksi Aeromonas hydrophila. Penelitian terdiri atas lima perlakuan yaitu budidaya ikan lele dumbo dengan penambahan probiotik Bacillus ND2, Bacillus P4I2, kombinasi probiotik Bacillus ND2 + Bacillus P4I2 (Kom), kontrol positif $(\mathrm{K}+)$, dan kontrol negatif (K-) (tanpa pemberian probiotik). Ikan lele dumbo $(13,354 \pm 2,8 \mathrm{~g})$ dipelihara pada akuarium volume $40 \mathrm{~L}$ dengan kepadatan 30 ekor per akuarium selama 30 hari. Bakteri probiotik ditambahkan pada media pemeliharaan ikan setiap hari diaplikasikan melalui air, sedangkan bakteri patogen A. hydrophila $\left(10^{3} \mathrm{CFU} / \mathrm{mL}\right.$ ) diberikan sekali saja pada awal pemeliharaan (kecuali pada kontrol negatif) karena sebagai asumsi bahwa A. hydrophila adalah patogen yang selalu ada di air dan akan membentuk quorum sensing jika kondisi kurang menguntungkan. Hasil penelitian menunjukkan bahwa laju pertumbuhan tertinggi dicapai pada perlakuan pemberian probiotik Bacillus ND2 yaitu sebesar $1,708 \pm 0,114 \%$ Pengamatan histopatologi menunjukkan bahwa pada perlakuan probiotik, terjadi kerusakan organ hati dan ginjal yang lebih ringan dibandingkan perlakuan kontrol positif $(\mathrm{K}+$ ). Pemberian probiotik Bacillus ND2 dengan dosis $10^{4} \mathrm{CFU} / \mathrm{mL}$ pada media pemeliharaan efektif meningkatkan pertumbuhan dan mencegah kerusakan hati dan ginjal ikan lele dumbo yang terserang Aeromoniasis.
\end{abstract}

KATA KUNCl: Aeromoniasis; Bacillus; lele; laju pertumbuhan; histopatologi; probiotik

ABSTRACT: The evaluation of probiotic bacillus on growth rate and histopathology changes of African catfish (Clarias gariepinus) infected by Aeromonas hydrophila. By: Angela Mariana Lusiastuti, Mohammad Faizal Ulkhaq, Widanarni, and Tri Heru Prihadi

The aim of this study was to evaluate the addition of a probiotic Bacillus through culture medium on growth rate and histopathological change in African catfish who was infected by Aeromonas hydrophila. The study consisted of five treatments such as the addition of probiotic Bacillus ND2, Bacillus P4I2, Bacillus ND2 + Bacillus P4I2 (Kom), positive control ( $\mathrm{K}+$ ) and negative control ( $\mathrm{K}$-) (without probiotic addition). African catfish (13.354 $\pm 2.8 \mathrm{~g}$ ) was maintained in 15 aquariums ( $40 \mathrm{~L}$ in volume) with 30 fishes each for 30 days. Probiotic bacteria was applied in water once a day, whereas pathogenic bacteria $\mathbf{A}$. hydrophila $\left(10^{3} \mathrm{CFU} / \mathrm{mL}\right)$ were added once in earlier treatment (except for the negative control) as assumption that $\mathbf{A}$. hydrophila will shape up quorum sensing in unfortunate condition. The result showed that the highest spesific growth rate in the treatment of Bacillus ND2 probiotics $(1,708 \pm 0.114 \%$. Histopathology showed that damaged of liver dan kidney in probiotics treatment were lightner than positive control $(K+)$. The addition of Bacillus P4I1 (104 CFU/mL) efective to increased the spesific growth rate of African catfish and prevent the damage of liver and kidney of African catfish was infected by Aeromoniasis.

KEYWORDS: Aeromoniasis; Bacillus; Clarias gariepinus; histopathology; probiotic

\footnotetext{
\# Korespondensi: Balai Penelitian dan Pengembangan Budidaya

Air Tawar. JI. Sempur No. 1, Bogor, Jawa Barat 16154,

Indonesia. Tel.: + (0251) 8313200

E-mail: Iusiastuti_61@yahoo.co.id
} 


\section{PENDAHULUAN}

Penyakit merupakan salah satu kendala pada budidaya ikan lele dumbo sistem intensif, di antaranya adalah Motile Aeromonads Septicaemia atau Aeromoniasis yang disebabkan oleh infeksi bakteri Aeromonas hydrophila. Bakteri A. hydrophila termasuk bakteri patogen oportunistik dan terdapat pada kolam budidaya ikan lele dumbo dengan persentase sebesar $25 \%$ dari total bakteri dalam media pemeliharaan (AlHarbi \& Uddin, 2010). Bakteri oportunistik berperan sebagai biofilter alami dalam proses perombakan bahan organik dalam air, serta tidak membahayakan organisme budidaya jika kondisi lingkungan budidaya dalam kisaran normal (Ibrahem et al., 2008). Penyakit Aeromoniasis sering menyerang ikan lele (Clarias sp.) dan jenis ikan air tawar tropis lainnya seperti dari golongan Siluridae, Ictaluridae, Clariidae, serta Cyprinidae. Tingkat kematian pada ikan lele dapat mencapai $80 \%$ bahkan 100\%dalam waktu sekitar satu minggu (Dini \& Purbomartono, 2009). Aeromonas hydrophila adalah patogen oportunis yang mempunyai strategi komunikasi antar bakteri yang disebut qourum sensing, jika mencapai qourum maka A. hydrophila mengeluarkan produk ekstra selulernya yang menyebabkan ikan menjadi sakit (Chen et al., 2010).

Pemilihan jenis dan dosis antibiotik yang tepat untuk pengendalian penyakit masih merupakan kendala dalam upaya manajemen penyakit pada budidaya ikan, termasuk penyakit Aeromoniasis. Efek samping dari penggunaan bahan antibiotik yang tidak tepat antara lain dapat menimbulkan resistensi pada bakteri patogen, mencemari lingkungan perairan, dan adanya residu kimia dari antibiotik pada produk perikanan yang dikonsumsi (Flores, 2011). Salah satu alternatif yang dapat dipilih untuk pencegahan penyakit ini adalah dengan aplikasi probiotik.

Probiotik didefinisikan sebagai mikroorganisme yang memiliki kemampuan untuk memodifikasi komposisi bakteri dalam saluran pencernaan hewan akuatik, air, dan sedimen, serta dapat digunakan untuk suplemen pakan yang dapat meningkatkan kesehatan inang dan berperan sebagai agen biokontrol (Flores, 2011). Salah satu mekanisme kerja probiotik di dunia perikanan yaitu dengan memproduksi komponen penghambat untuk menekan pertumbuhan bakteri patogen dalam perairan (Ibrahem, 2015). Bacillus merupakan salah satu jenis bakteri yang banyak dimanfaatkan sebagai probiotik dalam akuakultur karena kemampuannya menghasilkan enzim dan komponen antimikroba yang dapat menghambat bakteri patogen (Hong et al., 2004).

Pemeriksaan histopatologi organ dapat memberikan gambaran mengenai kondisi kesehatan ikan. Selain itu, pengamatan laju pertumbuhan ikan dapat digunakan sebagai salah satu indikator untuk mengevaluasi efektivitas pemberian probiotik pada media pemeliharaan. Chelladurai et al. (2013) menyatakan bahwa pemberian probiotik Lactobacillus acidophilus melalui pakan selama 60 hari pada ikan Mystus montanus dapat meningkatkan laju pertumbuhan spesifik dan memiliki patofisiologi hati dan insang yang lebih baik dibandingkan kontrol. Berdasarkan hal tersebut tujuan melakukan penelitian ini adalah mengevaluasi efek pemberian probiotik pada media pemeliharaan terhadap laju pertumbuhan dan perubahan histopatologi organ ikan lele dumbo yang diinfeksi Aeromonas hydrophila.

\section{BAHAN DAN METODE}

\section{Persiapan Isolat Probiotik dan Patogen}

Isolat probiotik yang digunakan merupakan kelompok bakteri Bacillus yang terdiri atas probiotik Bacillus ND2 yang diisolasi dari saluran pencernaan ikan nila (Oreochromis niloticus) (Lusiastuti \& Taukhid, 2011) dan Bacillus P4I2 yang diisolasi dari lingkungan budidaya ikan lele (Clarias sp.) (Novita et al., 2015), sedangkan bakteri patogen yang digunakan dalam penelitian ini adalah A. hydrophila AH26. Seluruh isolat bakteri merupakan koleksi dari Balai Penelitian dan Pengembangan Budidaya Air Tawar (BPPBAT), Bogor. Seluruh isolat bakteri dikultur pada media Trypticase Soy Broth (TSB) sebanyak $25 \mathrm{~mL}$ di dalam water bath shaker, $160 \mathrm{rpm}$ selama 24 jam pada $29^{\circ} \mathrm{C}$. Hasil kultur dipanen dan disentrifugasi pada 5.000 rpm selama 15 menit. Setelah itu, suspensi bakteri dicuci sebanyak dua kali dengan phosfat buffer saline (PBS; $\mathrm{NaCl} \mathrm{0,8} \mathrm{g;}$ $\mathrm{KH}_{2} \mathrm{PO}_{4} 0,2 \mathrm{~g} ; \mathrm{Na}_{2} \mathrm{HPO}_{4} 1,5 \mathrm{~g} ; \mathrm{KCl} 0,2 \mathrm{~g}$; dan akuades $1.000 \mathrm{~mL}$ ). Pengenceran berseri disesuaikan dengan dosis percobaan. Total Plate Count (TPC) bakteri ditentukan dengan metode cawan sebar (Madigan et al., 2011).

\section{Desain Penelitian pada Uji In Vivo}

Ikan uji yang digunakan adalah ikan lele dumbo sehat dan tidak menunjukkan gejala sakit dengan panjang $12,692 \pm 0,94 \mathrm{~cm}$ dan bobot $13,354 \pm 2,8 \mathrm{~g}$. Percobaan dilakukan pada akuarium berukuran $60 \mathrm{~cm}$ $x 70 \mathrm{~cm} \times 40 \mathrm{~cm}$ dengan volume air $40 \mathrm{~L}$ dan kepadatan 30 ekor per akuarium. Pemberian probiotik pada media pemeliharaan $\left(10^{4} \mathrm{CFU} / \mathrm{mL}\right)$, dilakukan setiap hari pada pagi hari selama 30 hari. Bakteri patogen A. hydrophila diberikan pada media pemeliharaan (kecuali kontrol negatif), sebanyak satu kali pemberian ( $10^{3} \mathrm{CFU} / \mathrm{mL}$ ) pada awal pemeliharaan (H0). Pakan berupa pelet komersial dengan kadar protein $36 \%$ diberikan secara at satiation setiap pagi dan sore hari. Selama pemeliharaan, akuarium tidak disipon dan tidak dilakukan pergantian air. Pengujian dilakukan sebanyak lima perlakuan dan tiga kali ulangan (Tabel 1). 
Tabel 1. Kombinasi perlakuan aplikasi probiotik Bacillus secara in vivo pada budidaya ikan lele dumbo (Clarias gariepinus)

Table 1. Combination treatment of probiotic Bacillus in vivo in African catfish

\begin{tabular}{lccc}
\hline \multirow{2}{*}{$\begin{array}{c}\text { Perlakuan } \\
\text { Treatments }\end{array}$} & \multicolumn{2}{c}{$\begin{array}{c}\text { Probiotik } \\
\text { Probiotic } \\
\text { (CFU/mL) }\end{array}$} & $\begin{array}{c}\text { Aeromonas hydrophila } \\
\text { (CFU/mL) }\end{array}$ \\
\cline { 2 - 3 } & ND2 & P412 & \\
\hline ND2 & $10^{4}$ & - & $10^{3}$ \\
P4I2 & - & $10^{4}$ & $10^{3}$ \\
Kom & $10^{4}$ & $10^{4}$ & $10^{3}$ \\
K+ & - & - & $10^{3}$ \\
K- & - & - & - \\
\hline
\end{tabular}

Parameter yang diamati pada penelitian ini adalah laju pertumbuhan spesifik, histopatologi hati dan ginjal, serta kualitas air meliputi suhu, oksigen terlarut (DO), derajat keasaman (pH), dan amonia. Laju pertumbuhan spesifik ikan dihitung mulai bobot awal sampai akhir penelitian berdasarkan Effendi (2002) yaitu:

$$
\mathrm{SGR}=\frac{\ln \mathrm{Wt}-\ln \mathrm{W}_{0}}{\mathrm{t}} \times 100
$$

di mana:

$$
\begin{array}{ll}
\mathrm{SGR} & =\text { laju pertumbuhan spesifik }(\%) \\
\text { In } \mathrm{Wt} & =\text { log natural bo bot ikan pada akhir pengamatan }(\mathrm{g}) \\
\text { In Wo } & =\text { log natural bobot ikan pada awal pengamatan }(\mathrm{g}) \\
\mathrm{t} & =\text { lama waktu pengamatan (hari) }
\end{array}
$$

Sampel untuk pengamatan histopatologi organ yang diambil hati dan ginjal dari satu ekor ikan dengan masing-masing perlakuan pasca infeksi berdasarkan metode yang dijelaskan oleh Hossain et al. (2007). Parameter kualitas air yang meliputi DO, suhu, pH, dan amonia diukur pada hari ke-0, 7, 14, 21, dan 28.

Rancangan yang digunakan pada penelitian ini adalah rancangan acak lengkap (RAL). Laju pertumbuhan spesifik dianalisis secara statistik menggunakan perangkat lunak IBM SPSS 16.0, pada selang kepercayaan 95\% (alpha $=0,05$ ). Apabila berbeda nyata, maka akan dilanjutkan dengan Duncan's Multiple Range Test (DMRT). Data histopatologi dianalisis secara deskriptif berdasarkan jumlah kerusakan pada organ ikan pada beberapa bagian organ. Jika jumlah kerusakan organ hanya di satu bagian (fokal), di beberapa tempat (multifokal), dan di semua tempat (difus), maka diberi tanda masing-masing,+++ , +++ (Adinata et al., 2012).

\section{HASIL DAN BAHASAN}

\section{Laju Pertumbuhan Spesifik}

Laju pertumbuhan spesifik ikan lele dumbo ditampilkan pada Gambar 1. Berdasarkan pengamatan laju pertumbuhan ikan selama 30 hari perlakuan, diketahui bahwa perlakuan pemberian probiotik Bacillus ND2 menunjukkan laju pertumbuhan yang signifikan lebih tinggi $(1,708 \%)$ dibanding perlakuan pemberian probiotik Bacillus $\mathrm{P} 4 \mathrm{I} 2$ (1,386\% dan kontrol positif $(\mathrm{K}+, 1,184 \%)(\mathrm{P}<0,05)$; akan tetapi tidak berbeda signifikan dengan perlakuan pemberian kombinasi probiotik (Bacillus ND2 + Bacillus P4I2) yaitu $1,512 \%$ dan kontrol negatif (K-) $1,548 \%(P>0,05)$. Selain itu, perlakuan pemberian probiotik Bacillus P4I2 tidak berbeda nyata dengan seluruh perlakuan kecuali perlakuan pemberian probiotik Bacillus ND2 $(P>0,05)$.

Berdasarkan hasil pengamatan laju pertumbuhan spesifik, pemberian probiotik Bacillus ND2 menunjukkan nilai pertumbuhan yang paling tinggi dibandingkan perlakuan lain, terutama kontrol. Hal ini diduga bahwa probiotik Bacillus ND2 memiliki kemampuan dalam merangsang pertumbuhan ikan lebih baik dibandingkan probiotik Bacillus P4I2. Perbedaan kemampuan ini diduga disebabkan karena perbedaan komponen yang dihasilkan oleh masing-masing bakteri probiotik untuk mempercepat proses pencernaan pakan menjadi energi. Cara kerja Bacillus ND2 di samping sebagai anti bakterial juga mempunyai kemampuan sebagai quorum quenching yaitu dapat mengeblok sinyal A. hydrophila ketika mencapai quorum. Selain itu, Bacillus ND2 juga mempunyai kemampuan sebagai immunostimulan dan dapat meningkatkan kecernaan pakan karena mempunyai enzim lipolitik, proteolitik, dan amilolitik. Bacillus P412 


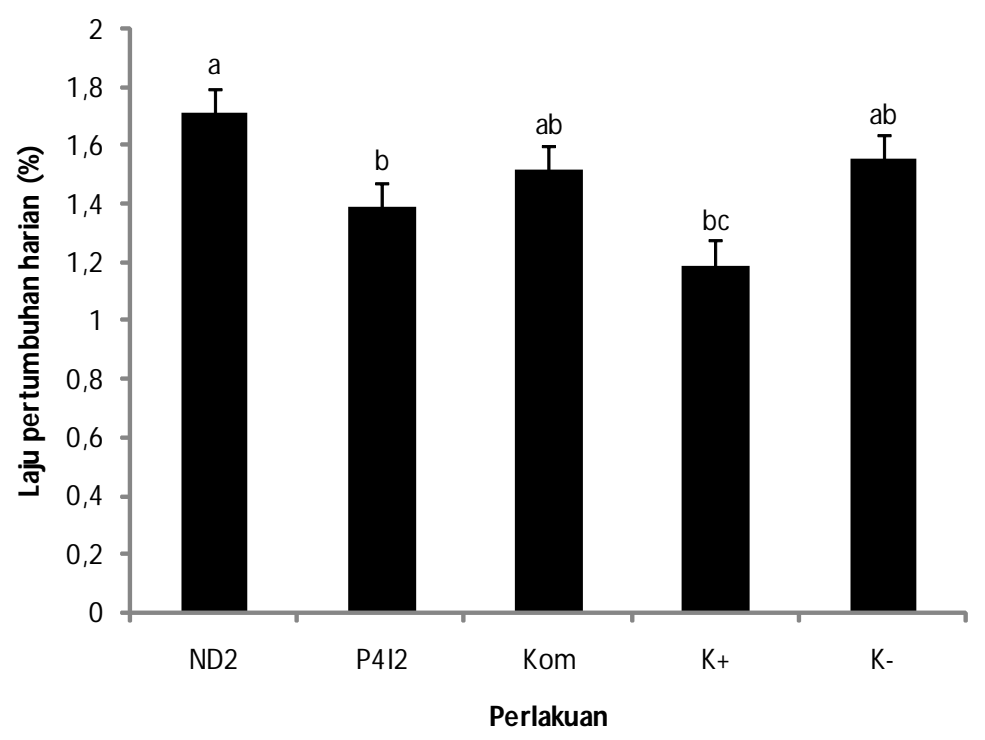

Keterangan (Note): Huruf yang berbeda menunjukkan hasil yang berbeda nyata $(P<0,05)$

Gambar 1. Laju pertumbuhan ikan lele dumbo (C. gariepinus) pada perlakuan probiotik Bacillus ND2, Bacillus P4I2, Kom (Bacillus ND2+ Bacillus P4I2) dan kontrol

Figure 1. Growth rate of African catfish (C. gariepinus) treated with probiotic Bacillus ND2, Bacillus P412, Kom (Bacillus ND2+ Bacillus P412) and control $(\mathrm{K}+$ and $\mathrm{K}-)$

adalah bakteri yang mempunyai kemampuan quorum quenching yang mencegah terbentuknya quorum sensing. Kemampuan Bacillus P412 belum cukup untuk membantu mengendalikan penyakit M otileAeromonads Septicemia yang diesebabkan oleh A. hydrophila. Hasil penelitian Sun et al. (2010) yang menyebutkan bahwa probiotik jenis Bacillus pumilus dan Bacillus clausii dapat meningkatkan performa pertumbuhan dan respons imun ikan Epinephelus coloides. Ziaei-Nejad et al. (2005) menyatakan bahwa probiotik Bacillus spp. yang diaplikasikan lewat media pemeliharaan dapat meningkatkan pertumbuhan dan tingkat sintasan udang putih India (Fenneropenaeus indicus). Peningkatan laju pertumbuhan spesifik ini sejalan dengan peningkatan survival rate dan paramater hematologi yang terdiri atas total eritrosit, total leukosit, kadar hematokrit, kadar hemoglobin, dan diferensial leukosit (Ulkhaq et al., 2014). Hal ini menandakan bahwa pemberian probiotik Bacillus ND2, selain mampu meningkatkan laju pertumbuhan ikan lele dumbo juga dapat meningkatkan tingkat sintasan dan imunitas ikan lele dumbo dari infeksi A. hydrophila. Hasil penelitian ini sejalan dengan hasil penelitian dari Abumourad et al. (2014) yang menyatakan bahwa pemberian probiotik Enterococcus faecium pada ikan Oreochomis niloticus melalui pakan dapat meningkatkan laju pertumbuhan ikan tersebut dan menunjukkan perubahan histopatologi yang lebih ringan dibandingkan kontrol setelah diuji tantang dengan $\mathrm{A}$. hydrophila.

Selain itu, peningkatan pertumbuhan diduga juga disebabkan karena penurunan tingkat stres ikan terhadap faktor kualitas air. Sehingga energi dari pakan yang masuk ke dalam badan ikan sebagian besar diarahkan untuk pertumbuhan. Fu et al. (2007) menyebutkan bahwa energi yang masuk dalam badan ikan yang berasal dari pakan akan sebagian besar digunakan untuk metabolisme, sebagian lagi digunakan untuk pertumbuhan dan sisanya dibuang dalam bentuk feses. Stres pada ikan menyebabkan penurunan pertumbuhan, tingkah laku yang abnormal, penurunan sistem imun ikan, dan resistensi terhadap penyakit (Lupatsch et al., 2010). Faktor penyebab stres (stressor) pada ikan dapat berasal dari kualitas air (Luz et al., 2008; Brogowski et al., 2005; Mallya, 2007), kepadatan (Naserizadeh et al., 2013), serta proses penanganan dan pengangkutan yang buruk (Adeyemo et al., 2009).

\section{Histopatologi}

Analisis histopatologi dapat digunakan sebagai biomarker untuk mengetahui kondisi kesehatan ikan melalui perubahan struktur yang terjadi pada organ 


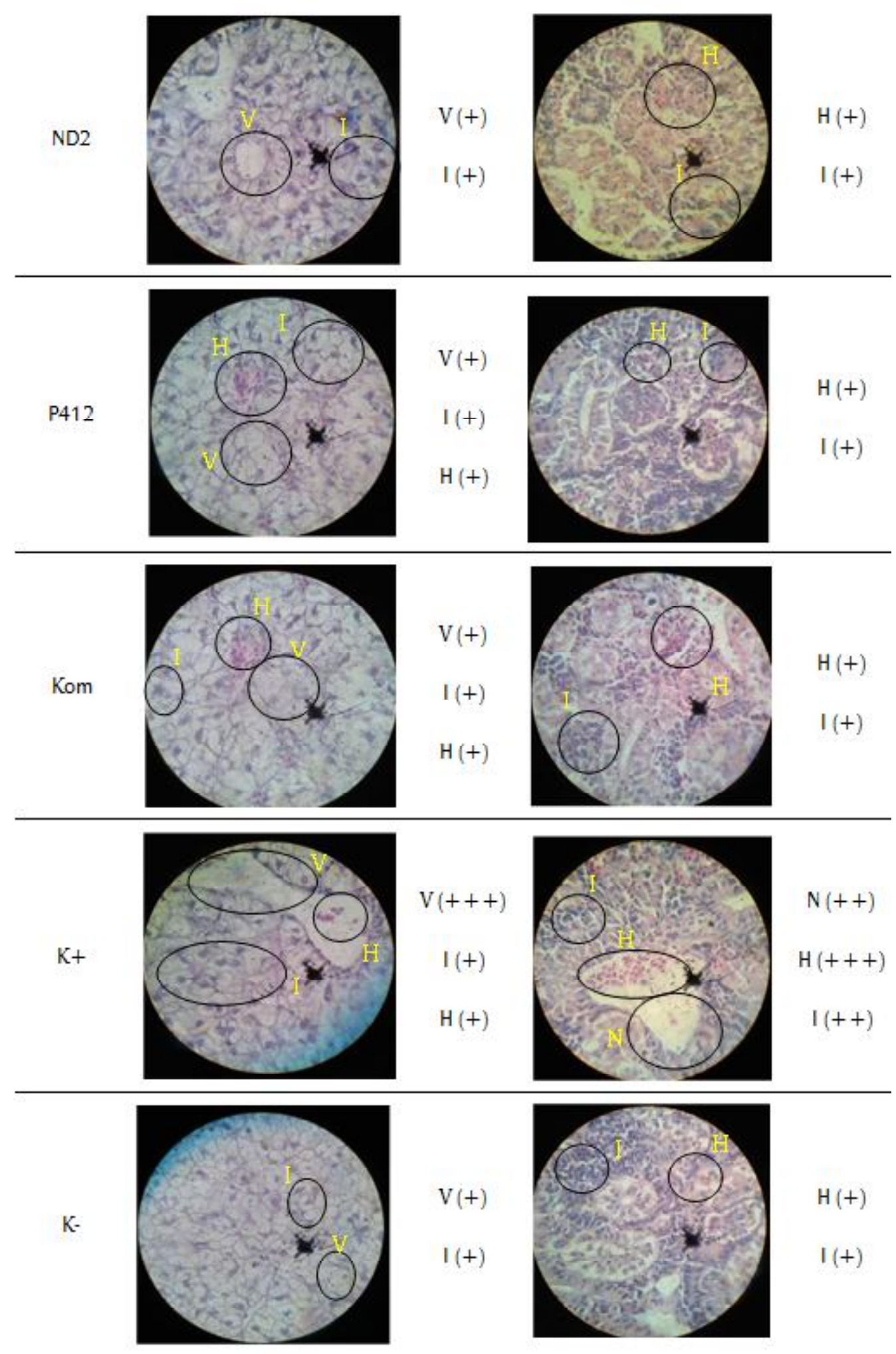

Keterangan (Note): + : Kerusakan sel fokal (focal cell necrosis), + + : kerusakan sel multifokal (multifocal cell necrosis), +++ : kerusakan sel difusa (diffuse cell necrosis); V: vakuolisasi (vacuolization), I: infiltrasi (infiltratation), H: Haemorrhagi (haemorrhage), $\mathrm{N}$ : Nekrosis (necrosis)

Gambar 2. Histopatologi hati dan ginjal ikan lele dumbo (Clarias gariepinus) pada perlakuan penambahan probiotik dan bakteri patogen dalam pemeliharaan selama 30 hari

Figure 2. Histopathological features of liver and kidney of African catfish (Clarias gariepinus) treated with probiotic and pathogen bacteria for 30 days 
dalam (Stentiford et al., 2014). Pemeriksaan histopatologi dalam penelitian ini dilakukan pada organ hati dan ginjal. Hal ini sesuai dengan pernyataan Laith \& Najiah (2013) yaitu gejala ikan yang terserang A. hydrophila adalah ikan lemas, nafsu makan menurun, nekrosis dan hipertropi pada kulit, hiperplasia dan infiltrasi leukosit pada insang, inflamasi pada ginjal, hati, dan limpa.

Hasil pengamatan histopatologi ikan uji (Gambar 2) menunjukkan bahwa terjadi infiltrasi (pemasukan) sel leukosit dan haemorrhagi pada hati dan ginjal pada seluruh perlakuan probiotik (ND2, P4I2, Kom), serta pada perlakuan kontrol ( $\mathrm{K}+$ dan K-). Khusus pada perlakuan kontrol positif $(K+)$, mengalami kerusakan paling parah, yaitu terjadi vakuolisasi sel epitel hati secara ekstensif, serta terjadi haemorrhagi dan nekrosis pada tubulus ginjal. Derajat kerusakan pada seluruh perlakuan probiotik dan kontrol negatif (K-) hanya terjadi secara fokal (+ ). Sedangkan pada perlakuan kontrol positif $(\mathrm{K}+)$ menunjukkan derajat kerusakan organ yang lebih parah yaitu berkisar pada multifokal sampai difus $(++$ sampai +++ ).

Pada seluruh perlakuan probiotik (ND2, P4I2, dan Kom), serta kontrol terjadi infiltrasi leukosit pada organ hati dan ginjal. Hal ini diduga terjadi karena ikan mulai berespons terhadap adanya patogen $A$. hydrophila dalam air, sehingga terjadi infiltrasi sel leukosit dalam organ hati dan ginjal. Rey et al. (2009) menyatakan bahwa infeksi A. hydrophila strain KJ 99 menyebabkan infiltrasi makrofag setelah dua jam pascainfeksi pada ikan tilapia hibrid (Oreochromis sp.). Pengamatan pada perlakuan kontrol positif $(K+)$ menunjukkan perubahan patologis yang paling parah dibandingkan perlakuan lain, yaitu terjadi vakuolisasi sel epitel hati secara ekstensif, serta terjadi haemorrhage dan nekrosis pada tubulus ginjal.

Hemoragi merupakan peristiwa keluarnya darah dari pembuluh darah dan banyak terdapat di kulit, membran mukosa, dan di antara sel-sel jaringan atau organ. Hemoragi dapat disebabkan oleh trauma, ruptur pembuluh darah atau peningkatan porositas akibat infeksi bakteri, virus atau bahan toksik. Sedangkan nekrosis adalah kematian sel-sel atau jaringan yang menyertai degenerasi sel pada setiap kehidupan hewan dan merupakan tahap akhir degenerasi yang irreversibel. Nekrosis dapat disebabkan oleh trauma, agen-agen biologis (virus, bakteri, jamur, dan parasit), agen-agen kimia atau terjadinya gangguan terhadap penyediaan darah pada suatu daerah khusus (Plumb, 1994). Pada hasil penelitian, vakuolisasi diduga terbentuk sebagai akibat gangguan mekanisme penyerapan nutrien sedangkan haemorrhage dan nekrosis terjadi karena adanya aktivitas toksin dan enzim yang dihasilkan oleh A. hydrophila. Hasil penelitian Miyazaki et al. (2001) menyebutkan bahwa ikan color carp (Cyprinus carpio) di Jepang yang terinfeksi virus corona dan $\mathrm{A}$. hydrophila mengalami haemorrhage pada hati, ginjal, limpa, dan permukaan kulit. Vakuolisasi pada sel hati juga ditemukan pada katak bullfrog (Rana catesbeiana) yang terinfeksi $A$. hydrophila (Priosoeryanto et al., 2000). Kelainan pada organ dalam ini disebabkan karena A. hydrophila menghasilkan produk ekstraseluler yang bersifat toksin bagi inangnya. Aberoum \& Jooyandeh (2010) mengemukakan bahwa Aeromonas menyekresikan beberapa jenis protein ekstraseluler, antara lain: amilase, chitinase, elastase, aerolysin, nuclease, gelatinase, lecithinase, lipase, dan protease.

Derajat kerusakan pada seluruh perlakuan probiotik dan kontrol negatif (K-) hanya terjadi secara fokal (+). Hal ini diduga karena efek pemberian probiotik yang dapat menurunkan jumlah patogen $A$. hydrophila sehingga tidak menyebabkan kerusakan organ yang parah. Sedangkan pada perlakuan kontrol positif $(\mathrm{K}+)$ menunjukkan derajat kerusakan organ yang lebih parah yaitu berkisar pada multifokal sampai difus $(++$ sampai +++ ). Hal ini diduga karena populasi patogen $A$. hydrophila pada media pemeliharaan yang tinggi dan tidak adanya bakteri probiotik di dalamnya yang berperan menurunkan jumlah patogen A. hydrophila. Hasil penelitian Ulkhaq et al. (2014) menyatakan bahwa terjadi penurunan jumlah bakteri patogen $\mathrm{A}$. hydrophila pada media pemeliharaan ikan lele dumbo yang diberi probiotik Bacillus.

\section{Kualitas Air}

Parameter kualitas air yang diamati pada penelitian ini adalah oksigen terlarut, suhu $\mathrm{pH}$, serta amonia yang diukur pada hari ke-0, 7, 14, 21, dan 28. Hasil pengamatan ditampilkan pada Tabel 2.

Berdasarkan hasil pengamatan suhu air selama penelitian, diperoleh nilai berkisar antara $26^{\circ} \mathrm{C}-28^{\circ} \mathrm{C}$. Nilai ini merupakan kisaran suhu optimum menurut Departement of Water Affairs and Forestry (1996), yaitu pada kisaran $25^{\circ} \mathrm{C}-30^{\circ} \mathrm{C}$. Di luar kisaran tersebut, ikan akan mengalami pertumbuhan yang lambat dan penurunan resistensi terhadap penyakit, terutama yang disebabkan karena infeksi bakteri dan jamur.

Pengukuran oksigen terlarut berkisar pada nilai 1,2-6,0 mg/L. Kondisi tersebut menunjukkan bahwa kandungan oksigen terlarut masih dapat ditoleransi menurut Departement of Water Affairs and Forestry (1996), yaitu pada kisaran 1-8 mg/L. Peningkatan kandungan oksigen terlarut dalam air sampai $>20$ $\mathrm{mg} / \mathrm{L}$ dapat menyebabkan supersaturasi pada yuwana dan larva ikan lele dumbo (Fourie, 2006). Oksigen 
Tabel 2. Kisaran nilai kualitas air media pemeliharaan ikan lele dumbo

Table 2. The average value of water quality in African catfish culture media

\begin{tabular}{|c|c|c|c|c|}
\hline \multirow{2}{*}{$\begin{array}{l}\text { Perlakuan } \\
\text { Treatments }\end{array}$} & \multicolumn{4}{|c|}{ Parameter (Parameters ) } \\
\hline & $\begin{array}{c}\text { Oksigen } \\
\text { Oxygen (mg/L) }\end{array}$ & $\begin{array}{c}\text { Suhu } \\
\text { Temperature }\left({ }^{\circ} \mathrm{C}\right)\end{array}$ & pH & $\begin{array}{c}\text { Amonia } \\
\text { Ammonia (mg/L) }\end{array}$ \\
\hline ND2 & $2.72-4.6$ & $26-28$ & $5-7.5$ & $0.01-0.03$ \\
\hline P4I2 & $2.7-5.4$ & $26-27$ & $5-7$ & $0.01-0.03$ \\
\hline Kom & $2.18-5.98$ & $26-27$ & $5.5-7$ & $0.02-0.04$ \\
\hline $\mathrm{K}+$ & $1.2-3.5$ & $25-27$ & $5-8$ & $0.01-0.14$ \\
\hline K- & $3.0-6.0$ & $26-28$ & $6-7$ & $0.01-0.14$ \\
\hline
\end{tabular}

terlarut dibutuhkan oleh ikan untuk menghasilkan energi dari pakan yang masuk ke dalam badannya. Sehingga jika DO dalam kondisi optimum maka metabolisme dalam badan ikan akan optimal dan energi yang dihasilkan akan banyak, sehingga akan banyak terdapat kelebihan energi yang dapat digunakan untuk pertumbuhan.

Nilai pH air pemeliharaan ikan lele dumbo berkisar antara 5-8. Nilai pH ini berada pada kisaran optimum untuk pemeliharaan ikan lele karena $\mathrm{pH}$ optimal untuk pertumbuhan ikan lele adalah 4,5-8,5 (Departement of Water Affairs and Forestry, 1996). Nilai pH dapat memengaruhi laju reaksi, serta tekanan osmosis dalam badan ikan, sehingga secara tidak langsung dapat memengaruhi pertumbuhan ikan.

Kadar amonia air pemeliharaan ikan lele dumbo mulai awal sampai akhir penelitian berkisar antara 0,010,14 mg/L. Kondisi ini masih aman untuk kehidupan dan pertumbuhan ikan lele dumbo karena kandungan amonia yang mampu ditolerir oleh ikan lele dumbo adalah 0-0,3 mg/L (Departement of Water Affairs and Forestry, 1996).

\section{KESIMPULAN DAN SARAN}

Pemberian probiotik Bacillus ND2 dengan dosis $10^{4}$ CFU/mL pada media pemeliharaan efektif meningkatkan laju pertumbuhan dan mencegah kerusakan hati dan ginjal ikan lele dumbo yang terserang Aeromoniasis.

\section{UCAPAN TERIMA KASIH}

Terima kasih kepada teknisi litkayasa Laboratorium Kesehatan Ikan; Saudara Edy Farid Wadjdy, Ahmad Wahyudi, Setiadi, dan Johan Affandi yang membantu kelancaran penelitian ini.

\section{DAFTAR ACUAN}

Aberoum, A., \& Jooyandeh, H. (2010). A review on occurrence and characterization of the Aeromonas species from marine fishes. World Journal of Fish; Marine Sciences, 2(6), 519-523.

Abumourad, I.M.K., Kenwy, A.M., Ibrahim, T.B., Hanna, M.I., \& Soliman, W.S. (2014). Enterococcus faecium probiotic as a growth promoter and its impact on the expression of the host innate immune in cultured Oreochromis niloticus. Reseach Journal of Pharmaceutical, Biological, and Chemical Sciences, 5(2), 1747-1761.

Adeyamo, O.K., Naigaga, I., \& Alli, R.A. (2009). Effect of handling and transportation on haematology of African catfish (Clarias gariepinus). Journal of Fisheries Sciences, 3(4), 333-341.

Adinata, M.O., Sudira, I.W., \& Berata, I.K. (2012). Efek ekstrak daun asibata (Angelica keisken) terhadap gambaran histopatologi ginjal mencit (Mus musculus). Buletin Veteriner Udayana, 4(2), 55-62.

Al-Harbi, A.H., \& Uddin, N.M. (2010). Bacterial populations of African catfish, Clarias gariepinus (Burchell 1822) cultured in earthen ponds. Journal of Applied Aquaculture, 22, 187- 193.

Brogowski, Z., Siewert, H., \& Keplinger, D. (2005). Feeding and growth responses of bluegill fish (Lepomis macrochirus) at various $\mathrm{pH}$ levels. Polish Journal of Environmental Studies, 14(4), 517-519.

Chelladurai, G., Felicitta, J., \& Nagarajan, R. (2013). Protective effect of probiotic diets on haematobiochemical and histopatology changes of Mystus montanus (Jerdon 1849) against Aeromonas hydrophila. Journal of Coastal Life Medicine, 1(4), 259-264.

Chen, R., Zhou, Z., Cao, Y., Bai, Y., \& Yao, B. (2010). High yield expression of an AHL-lactonase from Bacillus sp. B546 in Pichia pastoris and its application to reduce Aeromonas hydrophila mortality in aquaculture. Microbial Cell Factories, 9: 39 (doi:10.1186/1475-2859-9-39).

Department of Water Affairs and Forestry. (1996). South African Water Quality Guidelines, Volume 
6, Agricultural Use. Aquaculture Second Edition. Pretoria Republic of South Africa, 185 pp.

Dini, S.M., \& Purbomartono, M. (2009). Penggunaan vaksin polivalen dan vaksin polivalen plus sel Aeromonas hydrophila (penambahan vitamin $\mathrm{C}$ dan adjuvant) pada lele dumbo (Clarias gariepinus). Laporan Penelitian Hibah Bersaing Perguruan Tinggi XIII/1 perguruan Tinggi Anggaran 2008/2009 FKIP Universitas Muhammadiyah Purwokerto. Purwokerto, Indonesia.

Effendi, M.I. (2002). Biologi perikanan. Yayasan Pustaka Nusantara. Bogor, Indonesia.

Flores, M.L. (2011). The use of probiotic in aquaculture: an overview. International Research Journal of Microbiology, 2(12), 471-478.

Fourie, J.J. (2006). A practical investigation into catfish (Clarias gariepinus) farming in the Vaalharts irrigation scheme. Disertation. University of the Free State. 116 pp.

Fu, C., Li, D., Hu, W., Wang, Y., \& Zhu, W. (2007). Growth and energy budget of $F_{2}$ 'all-fish' growth hormone gene transgenic common Carp. Journal of Fish Biology, 70, 347-361.

Hong, H.A., Duc, L.H., \& Cutting, S.M. (2004). The use of bacterial spore formers as probiotics. FEMS Microbiology Reviews, 29, 813-835.

Hossain, M.K., Hossain, M.D., \& Rahman, H. (2007). Histopathology of some diseased fishes. Journal Life Earth Sciences, 2(2), 47-50.

Ibrahem, M.D., Mostafa, M.M., Arab, R.M.H., \& Rezk, M.A. (2008). Prevalence of A. hydrophila infection in wild and cultured tilapia nilotica (0. niloticus) in Egypt. $8^{\text {th }}$ International Symposium on Tilapia in Aquaculture 2008. p. 1257-1271.

Ibrahem, M.D. (2015). Evolution of probiotic in aquatic world: Potential effect, the current status in Egypt and recent prospective. Journal of Advanced Research, 6, 765-791.

Laith, A.R., \& Najiah, M. (2013). A. hydrophila: Antimicrobial susceptibility and histopathology of iso lates from diseased Catfish, Clarias gariepinus (Burchell). Aquaculture Research \& Development, 5(2), 1-7.

Lupatsch, I., Santos, G.A., Schrama, J.W., \& Verreth, J.A.J. (2010). Effect of stocking density and feeding level on energy expenditure and stress responsiveness in European sea bass Dicentrarchus labrax. Aquaculture, 298, 245-250.

Lusiastuti, A.M., \& Taukhid. (2011). Seleksi kandidat probiotik anti Aeromonas hydrophila untuk pengendalian penyakit ikan air tawar. Balai Riset Perikanan Budidaya Air Tawar. Bogor, $13 \mathrm{hlm}$.
Luz, R.K., Martinez-Alvarez, R.M., De Pedro, N., \& Delgado, M.J. (2008). Growth, food intake regulation and metabolic adaptation in Goldfish (Carassius auratus) exposed to different salinities. Aquaculture, 276, 171-178.

Madigan, M.T., Martinko, J.M., \& Parker, J. (2011). Brock biology of microorganisms. $13^{\text {th }}$ Edition. Prentice-Hall Inc., USA.

Mallya, Y.J. (2007). The effect of dissolved oxygen on fish growth in aquaculture [final project]. Kingolwira National Fish Farming Centre, Fisheries Division Ministry of Natural Resources dan Tourism Tanzania. 30 pp.

Miyazaki, T., Kageyama, T., Miura, M., \& Yoshida, T. (2001). Histopathology of viremia-associated anaaki-byo in combination with $A$. hydrophila in color carp Cyprinus carpio in Japan. Diseases of Aquatic Organism, 44, 109-120.

Naserizadeh, M., Nematollahi, M.A., \& Hosseini, S.V. (2013). The relationship between water quality parameters and response to density stress in Pacu (Piaractus brachypomus). International Research Journal of Applied; Basic Sciences, 4(6), 1518-1523.

Novita, H., Rusmana, I., Yuhana, M., \& Pasaribu, F.H. (2015). Karakterisasi bakteri anti quorum sensing (AQS) sebagai penghambat virulensi penyakit pada ikan lele dumbo (Clarias gariepinus). J. Ris. Akuakultur, 10(1), 72-81.

Plumb, J.A. (1994). Health maintenance of cultured fishes. Principal Microbial Disease. CRC Press, United States, 239 pp.

Priosoeryanto, B.P., Huminto, H., Agungpriyono, D.R., Harlina, E., Estuningsih, S., \& Simanullang, S.T.P. (2000). Studi patologi dari abses multifokal pada katak (Rana catesbeiana). Seminar Nasional Peternakan dan Veteriner, $4 \mathrm{hlm}$.

Rey, A., Verján, N., Ferguson, H.W., \& Iregui, C. (2009). Pathogenesis of $A$. hydrophila strain $\mathrm{KJ} 99$ infection and its extracellular products in two species of fish. Veterinary Record, 164, 493-499.

Stentiford, G.D., Massoud, M.S., Al-Mudhhi, S., AlSarawi, M.A., Al-Enezi, M., \& Lyons, B.P. (2014). Histopathological survey of potential biomarkers for the assessment of contaminant related biological effect in species of fish and shellfish collected from Kuwait Bay, Arabian Gulf. Marine Environmental Research, 98, 60-67.

Sun, Y.Z., Yang, H.L., Ma, R.L., \& Lin, W.Y. (2010). Probiotic applications of two dominant gut Bacillus strains with antagonistic activity improved the growth performance and immune responses of grouper Epinephelus coioides. Fish and Shellfish Immunology, 29, 803-809. 
Ulkhaq, M.F., Widanarni, \& Lusiastuti, A.M. (2014). Aplikasi probiotik Bacillusuntuk pencegahan infeksi Aeromonas hydrophilla pada ikan lele. Jurnal Akuakultur Indonesia, 13(2), 105-114.
Ziaei-Nejad, S., Rezaei, M.H., Takami, G.A., Lovett, D.L., Mirvaghefi, A.R., \& Shakouri, M. (2005). The effect of Bacillus spp. bacteria used as probiotics on digestive enzyme activity, survival, and growth in the Indian white shrimp Fenneropenaeus indicus. Aquaculture, 252(2-4), 516-524. 